PF 2019 (LXXIII): 165-185

\author{
ANNA LEDZIŃSKA \\ Pracownia Łaciny Średniowiecznej \\ Instytut Języka Polskiego PAN \\ al. Mickiewicza 31, 31-120 Kraków \\ tel. (+48) 126325692 wew. 342 \\ e-mail: anna.ledzinska@ijp-pan.krakow.pl
}

\title{
SANCTUS VIR SED NON FEMINA. \\ BADANIA LEKSYKALNE PRZYMIOTNIKA SANCTUS \\ Z WYKORZYSTANIEM KORPUSU POLSKIEJ HAGIOGRAFII ŚREDNIOWIECZNEJ ${ }^{1}$
}

SŁOWA KLUCZOWE: łacina średniowieczna, pojęcie świętości, badania korpusowe

KEYWORDS: medieval Latin, notion of sanctity, corpus-based study

SANCTUS VIR SED NON FEMINA.

A LEXICAL STUDY OF THE ADJECTIVE SANCTUS

BASED ON THE CORPUS OF THE POLISH MEDIEVAL HAGIOGRAPHY

\begin{abstract}
The article tends to scrutinize the change of meaning and collocation patterns of the adjective sanctus in a diachronic perspective from the classical times, through the patristic period and up to the Middle Ages, taking into consideration the regional diversification of the Latin language. Definitions and examples are taken from various scientific dictionaries and lexicons, whereas the Polish medieval specifics of the usage of the word is analyzed on the basis of Dictionary of the Medieval Latin from Polish Sources and Corpus of the Polish Medieval Hagiography. The corpus containing Lives and Miracles of the Polish saints is a subdivision of the big Corpus of Medieval Latin in Polish Lands. All the queries were being led using multi-tool platform TXM.
\end{abstract}

\footnotetext{
1 Artykuł powstał częściowo w ramach projektu „Fontes Mediae et Infimae Latinitatis Polonorum. Korpus łaciny średniowiecznej na ziemiach polskich 1000-1550" finansowanego ze środków NPRH (0045/FNiTP/H11/80/2011).
} 
W języku łacińskim nośnikami znaczenia 'święty' jest wiele przymiotników, takich jak augustus, beatus, benedictus, divus, divinus, felix, sacer, sacratus, sanctus, sacrosanctus. Szczegółowe przedstawienie semantyki i łączliwości wszystkich tych wyrazów wymagałoby bardzo obszernego opracowania, dlatego w niniejszym artykule omówiony zostanie tylko jeden z nich - sanctus, który jest najbardziej rozpoznawalnym leksykalnym wykładnikiem tego pojęcia, znanym także osobom niemającym częstej styczności z łaciną. Przedmiotem szczególnego zainteresowania będą tu aspekty znaczenia i funkcjonowania słowa sanctus ('święty') charakterystyczne dla łaciny polskiego średniowiecza. Dodatkowym argumentem przemawiającym za uznaniem tego właśnie przymiotnika za dobrego reprezentanta grupy synonimów jest jego duże rozpowszechnienie w łacinie średniowiecznej ziem polskich, a więc w docelowym obszarze niniejszych badań. Wprawdzie ekscerpcja źródeł na potrzeby Słownika łaciny średniowiecznej w Polsce (SŁŚ) nie wyczerpuje wszystkich wystąpień tekstowych opracowywanych tam wyrazów, jednak liczba odnotowanych w kartotece poświadczeń daje wyobrażenie o ich faktycznej frekwencji w materiale źródłowym². Można zatem przyjąć, iż ponad sto trzydzieści wypisów źródłowych odnoszących się do przymiotnika sanctus w stosunku do około sześćdziesięciu związanych z przymiotnikiem beatus - drugim najważniejszym nośnikiem znaczenia 'święty' - stanowi pewną wskazówkę co do proporcji ich występowania w łacińskich tekstach średniowiecznych powstałych na ziemiach polskich ${ }^{3}$.

Na podstawie wybranych słowników w pierwszej kolejności zostaną omówione znaczenia, idiomatyka i łączliwość wyrazu sanctus w łacinie klasycznej oraz symultanicznie - na podstawie słowników łaciny kościelnej i średniowiecznej - zmiany semantyczne tego słowa, jakie dokonały się w późniejszych epokach. $\mathrm{Na}$ końcu zaś ukazane zostaną zjawiska charakterystyczne dla łaciny średniowiecznej ziem polskich. Materiałem badawczym jest z jednej strony leksyka zgromadzona w SŁŚ, z drugiej - w bliższym kadrze - wyniki uzyskane w trakcie procesowania danych Korpusu Polskiej Hagiografii Średniowiecznej. Taki porządek prezentacji umożliwi z jednej strony diachroniczne prześledzenie rozwoju znaczeń badanego leksemu, z drugiej pozwoli podkreślić pożytki płynące z komplementarnego wykorzystania zasobów leksykograficznych i korpusowych dla tego rodzaju badań.

Wybór leksykonów łaciny klasycznej jest szeroki, jednak niewiele z nich spełnia wymogi słownika naukowego i zawiera wystarczającą egzemplifikację w postaci cytatów. Niniejsze studium opiera się na Oxford Latin Dictionary (OLD) ${ }^{4}$,

\footnotetext{
2 Do tego zagadnienia powrócę $\mathrm{w}$ dalszej części wywodu.

Por. http://rcin.org.pl/dlibra/publication?id=31986\&from $=\&$ dirids $=1 \&$ tab $=1 \& l p=1 \& Q I=$ oraz http://rcin.org.pl/dlibra/publication?id=31986\&from=\&dirids=1\&tab=1\&lp=1\&QI= (dostęp 15.01.2017).

4 O charakterystyce, zaletach i ograniczeniach tego dzieła por. Henderson 2010.
} 
pod redakcją Petera Glare’a, Słowniku łacińsko-polskim pod redakcją prof. Józefa Korpantego (SŁP), komplementarnie również na starszym słowniku A new Latin Dictionary... pod redakcją Charltona T. Lewisa i Charlesa Shorta (LD) oraz na leksykonie Totius Latinitatis Lexicon zredagowanym przez Egidiusza Forcelliniego (TLForc). Pierwsze spośród wymienionych opracowań obejmują jedynie materiał do roku 200 n.e., a ostatni sięga epoki patrystycznej. Nie został uwzględniony natomiast Thesaurus Linguae Latinae (ThLL), który zawiera obecnie hasła do $\mathrm{REDDO}^{5}$, a dodatkowo hasła rozpoczynające się na niektóre litery pośrod$\mathrm{ku}$ alfabetu pominięto ${ }^{6}$. Już leksykon Forcelliniego uwzględnia częściowo łacinę kościelną wyrastającą z literatury patrystycznej, jednak podstawowym kompendium wiedzy o tego rodzaju leksyce pozostaje Dictionnaire latin-francais des auteurs chrétiens opracowany przez Alberta Blaise’a (BlChr) ${ }^{7}$. Pomocny w niniejszych badaniach okazał się również polskojęzyczny słownik opracowany przez ks. Alojzego Jougana na podstawie publikacji Blaise’a (SŁK). Jeśli chodzi o słowniki łaciny średniowiecznej, to na pierwszym miejscu wymienić należy Glossarium mediae et infimae Latinitatis pod redakcją Charlesa F. DuCange’a (GMIL) ${ }^{8}$. Novum Glossarium zostało pominięte, ponieważ nie ma w nim omawianego tu hasła9. Dalej wymienić trzeba niewielki, lecz ważny Mediae Latinitatis Lexicon Minus Jana F. Niermayera, a następnie szereg słowników narodowych ${ }^{10}$ : leksykon łaciny włoskiej pod red. Francesca Arnaldiego i Pasquale Smiragli (LIML), łaciny węgierskiej Antala Bartala (GMLH), holenderskiej (LLNM) ${ }^{11}$, szwedzkiej $(G M L S)^{12}$, fińskiej (GMLF 1925 i GMLF 1958), angielskiej (DMLB) ${ }^{13}$, jugosłowiańskiej (GMLI) (Sharpe 1996, s. 104). Polska specyfika występowania, znaczeń i łączliwości przymiotnika sanctus opisana zostanie na podstawie przywoływanego już SŁŚ ${ }^{14}$.

5 ThLL, vol. XI, fasc. III, Oldenbourg 2016.

6 Por. Hays 2007.

7 Nie został tutaj wykorzystany niewielki wokabularz liturgiczny tego autora (Blaise 1966), ponieważ w badanym zakresie materiał tam zgromadzony nie zmienia w żaden sposób obrazu sytuacji. Dodatkowo wykorzystano jednak BlM.

8 O ile nie zaznaczono inaczej, cytaty odnoszą się do: GMIL, t. VII, Paris 1938.

9 Ostatni zeszyt obejmuje hasła Pleguina-Polutus, por. Guerreau-Jalabert et al. 2015.

10 Nie wykorzystano słowników, które nie obejmują jeszcze hasła sanctus, a więc MLW (A-I), GMLC (A-G), LMB (A-M); LMH (A-C).

11 Jeśli nie zaznaczono inaczej, adres bibliograficzny odnosi się do: LLNM, fol. 55 ROTOND...-SCABINALIS, red. O. Weijers, M. Gumbert Hepp, Leiden-Boston-Köln 2001.

12 Jeśli nie zaznaczono inaczej, adres bibliograficzny odnosi się do: GMLS, vol. II, fasc. 6 Sabaterius-Zundensis, red. E. Odelman, Stockholm 2002.

13 Jeśli nie zaznaczono inaczej, adres bibliograficzny odnosi się do: DMLB, fasc. XV Sal-Sol, red. D.R. Howlet, R.K. Ashdowne, Oxford 2012.

14 Jeśli nie zaznaczono inaczej, adres bibliograficzny odnosi się do: SŁŚ, t. VIII, fasc. 5(67), red. M. Rzepiela, Kraków 2007. 
W łacinie starożytnej przymiotnik sanctus ma trzy główne znaczenia. Po pierwsze więc, oznacza 'uświęcony, chroniony sankcją kultową, nietykalny, nienaruszalny' (SŁP s. 682, pkt I.1) ${ }^{15}$. Doskonałe definicje, które pozwalają wyeksponować to właśnie znaczenie omawianego wyrazu, znaleźć można u dwóch autorów epoki cesarstwa. Jednym z nich jest teoretyk prawa Ulpian (II/III w. n.e.), który pisze: „Proprie dicimus sancta, quae neque sacra neque profana sunt, sed sanctione quadam confirmata, ut sunt leges, quia sanctione quadam subnixae sunt"16 (TLForc, s. 213) ${ }^{17}$. Natomiast w dziele De verborum significatu wydanym i opracowanym przez Festusa (II w. n.e.) na podstawie niezachowanych prac Verrusa Flaccusa znajdujemy zapis: „Inter sacrum autem, et sanctum, et religiosum differentias bellissime refert (Gallus): sacrum aedificium, consecratum deo; sanctum murum, qui sit circum oppidum; religiosum sepulcrum, ubi mortuus sepultus aut humatus sit, satis constare ait"18 (OLD, s. 1687, pkt 1e) $)^{19}$. Cytaty dowodzą, że w tym znaczeniu sanctus nie odnosi się do bóstwa, co uznają także autorzy słowników, wskazując na specjalizację znaczeniową. Leksykony bowiem potwierdzają, że jakakolwiek rzecz, miejsce itp. poświęcone bóstwu otrzymuje w łacinie klasycznej określenie sacer, natomiast miano sanctus przysługuje każdemu miejscu, sprawie i osobie w przestrzeni publicznej, które są nienaruszalne, nietykalne (LD, s. 1625, pkt A). Przykładem takiego właśnie rozumienia omawianego przymiotnika jest przywoływane przez Marka Maniliusza (I w. p.n.e.) określenie aerarium sanctius, czyli nazwa specjalnego skarbca zawierającego rezerwy na wypadek wojny (OLD, pkt 1c). W klasycznej łacinie przymiotnika sanctus w znaczeniu 'nietykalny' używano także w odniesieniu do ludzi, pojawia się on na przykład u Cezara w Wojnie galijskiej w opisie świętego prawa gościnności praktykowanego przez Germanów: „qui ... ad eos venerunt ab iniuria prohibent,

15 Ta i poniższe definicje polskie znaczeń klasycznych cytowane za SŁP.

16 „Poprawnie określamy jako rzeczy usankcjonowane/nietykalne te, które nie są ani uświęcone, ani pozbawione charakteru sakralnego, lecz potwierdzone jakąś sankcją, tak jak prawa są nienaruszalne, ponieważ oparte są na jakiejś sankcji”. Wszystkie tłumaczenia, o ile nie zaznaczono inaczej, wyszły spod pióra autorki artykułu. Takie rozwiązanie podyktowane jest względami praktycznymi - przekłady literackie zawierające potrzebne cytaty oddają fragmenty w szerszym kontekście, a zatem często pozbawione są dosłowności i precyzji, które niezbędne są przy egzemplifikacji omawianych rozróżnień semantycznych.

17 Cytaty z tekstów oryginalnych podaję konsekwentnie za przywoływanymi słownikami, między innymi ze względu na niedostępność części źródeł słowników średniowiecznych, które tworzone są nie tylko na podstawie wydań krytycznych tekstów z epoki, ale też manuskryptów i starodruków

18 „Różnice zaś pomiędzy uświęconym a usankcjonowanym i religijnym świetnie oddaje (Gallus); mówi on, że dobrze wiadomo, że uświęcony [jest] budynek poświęcony bogu, usankcjonowany/nietykalny [jest] mur, który opasuje miasto, a otoczony czcią religijną [jest] grób, gdzie został pogrzebany zmarły".

19 Hasło sanctus mieści się w OLD w całości na s. 1687, tak więc w dalszej części wywodu numer strony nie będzie przywoływany. 
sanctos habent"20 (OLD, pkt 1b). Święte i nienaruszalne są też prawa, powzięte zobowiązania, przysięgi (lex, fides, iusiurandum), jakkolwiek Cyceron rzeczowo konstatuje w mowie Pro Quinctio: „nullum esse officium tam sanctum ... quod non avaritia ... violare soleat" ${ }^{21}$ (OLD, pkt 1a). Warto tutaj dodać, że w istocie już w antyku znaczenia sanctus i sacer interferowały i pokrywały się częściowo w praktyce językowej zachowanej przez zabytki piśmienne, jednak gramatycy późnej starożytności, glosatorzy i encyklopedyści, tacy jak wyżej wspomniani Ulpian, Flaccus i Festus czy np. Izydor z Sewilli, toczyli żywą dyskusję zmierzającą do wyraźnego rozróżnienia terminów sanctus, sacer, religiosus, także antonimicznego do nich - profanus (Fugier 1963; Schilling 1971; Schmitt 1992).

W drugim, bardzo powszechnym w starożytności znaczeniu sanctus wyraża treść 'święty, błogosławiony, boski, czcigodny, dostojny' (SŁP, s. 682, pkt I.2) i odnosi się do wszystkiego, co w jakikolwiek sposób znaczeniowo związane jest z bogami. Mówi się tak więc bezpośrednio o bogach - np. Katullus o Wenerze i Kupidynie (OLD, pkt 3a), ale też o rzeczach i miejscach im poświęconych, np. o rzece Tyber, wróżebnych ptakach obserwowanych przez Romulusa przed założeniem Rzymu, o świątyniach i grobowcach (OLD, pkt 2). Co więcej, przymiotnikiem sanctus opisuje się również poetów i wieszczków oraz ich wypowiedzi - tak pisał Owidiusz o natchnionej boską inspiracją wieszczce Karmentis oraz Horacy o starodawnych, a wciąż podziwianych poematach, takich jak Bellum Punicum Newiusza (OLD 3b). Komponent znaczeniowy odnoszący się do sakralności jest ewokowany również wtedy, gdy słowo sanctus aplikowane jest do zmarłych, jak np. w XI księdze Eneidy Wergiliusza, gdzie Ewander po śmierci syna Pallasa zwraca się do swej zmarłej żony, która szczęśliwie nie dożyła tej tragicznej chwili: „tu ... o sanctissima coniunx, felix morte tua”22 (OLD, pkt 3c) ${ }^{23}$. Wyraz sanctus występuje także w tych kontekstach, w których mówi się o rodzicach (OLD, pkt 3d), o senacie i innych ważnych instytucjach (OLD, pkt 3e). Zyskuje wówczas dodatkowy element semantyczny o podłożu pragmatycznym związany z wyrażaniem szczególnego poszanowania, oddawaniem czci ludziom lub szacunku instytucjom.

Z połączenia tych dwóch walorów - świętości jako bliskości bogom oraz świętości jako wymogu szczególnej czci - zrodziło się inne jeszcze użycie przymiotnika sanctus, które zostało kulturowo sformalizowane jako titulus honorificus

„Tych, którzy ... do nich przybyli chronią od krzywd i mają za nietykalnych”.

„Nie istnieje żadne zobowiązanie tak święte ... by nie mogła go pogwałcić chciwość”.

„Ty, o najczcigodniejsza żono, szczęśliwa przez swą śmierć”.

23 Należy tu dodać, że spośród przywoływanych słowników łaciny klasycznej jedynie OLD wyróżnia to znaczenie, natomiast pozostali leksykografowie zamieszczone w tym punkcie cytaty przypisują do innych znaczeń; por. np. atrybucję przywołanego tutaj cytatu z Wergiliusza w LD, s. 1625 do punktu B2 odnoszącego się do opisu cech moralnych człowieka. 
w późniejszych epokach. Po raz pierwszy Owidiusz w Fasti użył tego określenia w odniesieniu do Augusta, podobnie Waleriusz Flakkus pisał o cesarzu Wespazjanie (LD, s. 1625, pkt B1).

Trzecie znaczenie oddawane w słowniku pod red. Korpantego jako 'prawy, nieskazitelny, cnotliwy, moralnie czysty' (SŁP, s. 682m pkt I 3) odnosi się do cech człowieka i jego działań. Cyceron w mowie W obronie Archiasza tak pisał o Metellusie: "homo sanctissimus modestissimusque omnium” ${ }^{24}$ (OLD, pkt 4a). Ten sam używa określenia sanctus w odniesieniu do miłości platonicznej: „Ne amores quidem sanctos a sapiente alienos esse arbitrantur" ${ }^{25}$, u innych autorów znaleźć można zestawienie sancta anima, cura - 'prawa dusza, święta troska', sanctus pudor, mos - 'cnotliwy wstyd, moralnie doskonały obyczaj' (OLD, pkt 4b). Sancta oratio interpretowana jest jako mowa pełna powagi, wstrzemięźliwa pod względem stylu i zawartości (OLD, pkt 4c).

W późnej starożytności i w średniowieczu najbardziej rozwinęły się te dwa ostatnie znaczenia pod wpływem Biblii i doktryny chrześcijańskiej ${ }^{26}$. Ponieważ przenikają się one i łączą na wielu poziomach, słowniki zaś przedstawiają ten materiał w sposób bardzo zróżnicowany, konieczne było przyjęcie tutaj jakiejś zasady porządkującej. W związku $\mathrm{z}$ tym za punkt odniesienia przyjęto osobę lub rzecz, do której przymiotnik sanctus jest aplikowany. Zgodnie z tą optyką najważniejszym obiektem określanym tym mianem był Bóg - 'święty, nieskazitelny, doskonały'. Sanctus w formie zsubstantywizowanej zastępuje wręcz wyraz deus w Piśmie Świętym i u ojców Kościoła (BlChr, s. 736, pkt 4). Pod wpływem języka hebrajskiego używano w Wulgacie (IV w. n.e.) miana tersanctus - trzykroć świętego: „sanctus, sanctus, sanctus Dominus Deus exercituum”27 (Vulg. Is 6,3). Pierwotne znaczenie tej kumulacji biskie było superlatiwowi, jednak z czasem ojcowie Kościoła zaczęli interpretować je jako odniesienie do tajemnicy Trójcy Świętej. Ten cytat stał się też źródłem pierwszej części hymnu wykorzystywanego od V w. w liturgii Kościoła rzymskokatolickiego jako część modlitwy eucharystycznej (Mazza 1999, s. 285). Z czasem wyraz sanctus, często w formie nieodmiennej, uległ leksykalizacji i stał się synonimem wspomnianej wyżej aklamacji z modlitwy poprzedzającej Ofiarowanie (por. np. GMLF(1958), s. 161; DMLB,

24 „Człowiek najbardziej ze wszystkich umiarkowany i najbardziej prawy”.

25 „Uważa się, że miłość czysta nie jest całkiem niestosowna dla mędrca”.

26 Pisarze chrześcijańscy przyjmowali różne strategie, by dopasować język łaciński do opisu doktryny chrześcijańskiej. Częściowo polegało to na słowotwórstwie lub przenoszeniu na łaciński grunt terminów biblijnych greckich i hebrajskich, częściowo zaś na nadawaniu nowych znaczeń słowom istniejącym lub przesuwaniu ich pól znaczeniowych jak to ma miejsce w omawianym przypadku. Por. Brown 1996, s. 93-105; Bourgain 2005, s. 23-25.

27 „Święty, święty, święty Pan Bóg zastępów”. 
s. 2926, pkt 3c). Mógł też oznaczać inne krótkie modlitwy rozpoczynające się od tego słowa (GMIL kol. 301a).

Przymiotnik sanctus odnosi się również do trzeciej osoby Trójcy Świętej. Zbitkę sanctus Spiritus znaleźć można już w Nowym Testamencie (np. Vlg. Act. 1,5), w czasach patrystycznych zaś uległa ona całkowitemu utrwaleniu (BlChr, p. 771, pkt 10). Z kolei zestawienie Sanctus Dei związane jest z Chrystusem, tak w Nowym Testamencie - „Scio qui sis Sanctus Dei” (Vulg. Marc. 1,24) - jak i np. u Tertuliana (II/III w. n.e.) (BlChr, s. 736, pkt 4). W odniesieniu do Chrystusa u autorów średniowiecznych, takich jak Alkuin (VIII w.), Ordericus Vitalis (XII w.) czy kaznodzieja John of Ford (XIII w.), używany był także tzw. superlativus hebraicus w formie Sanctus sanctorum (DMLB s. 2927, pkt 4c; GMLI, s. 702). Junktura sancta Trinitas rozpowszechniła się w tekstach łacińskich dosyć późno (DMLB, s. 2926, pkt 1a), jakkolwiek samo słowo trinitas występuje już w rozważaniach Tertuliana (BlChr, s. 829 pkt 2), czyli przed wypracowaniem dogmatu o Trójcy Świętej podczas soborów: nicejskiego (325 r. n.e.), konstantynopolitańskiego I (381 r. n.e.) oraz II soboru w Konstantynopolu (553 r.), na którym ostatecznie zatwierdzona została nauka o Trójcy Świętej (Słomka 2013, s. 1050-1051). Należy tu jeszcze nadmienić, że sanctus stanowi ponadto w łacińskiej Biblii synonim anioła (BlChr, s. 736, pkt 5).

W odniesieniu do ludzi omawiany przymiotnik stosowany był w kilku funkcjach - po pierwsze, w funkcji opisowej pojawiał się wtedy, gdy pisano o człowieku 'zacnym, nieposzlakowanym, czystym' (SŁK, s. 603, pkt 3), 'wiodącym życie godne świętego'. I tak na przykład w utworze Peregrinatio ad loca sancta przypisywanym Egerii (IV w. n.e.) pisze się o „monachi veri sancti”28, Augustyn zaś zwraca się tak do swych korespondentów: „mi Pauline, sancte homo Dei”29 (BlChr, s. 737, pkt 8). Po drugie, przymiotnik występował często w formie urzeczownikowionej na oznaczenie człowieka wiernego Bogu, np. u św. Augustyna i Ambrożego (IV/V w. n.e.), a także jednego z patriarchów w Starym Testamencie (BlChr, s. 736, pkt. 6). Ponadto określano tak męczenników i apostołów (BlChr, s. 736-737, pkt 7), a szerzej każdego wiernego chrześcijanina, członka Kościoła. Wspólnota chrześcijańska określana była mianem chorus sanctorum, limina sanctorum (GMLI s. 702). Mianem sanctus określano również zmarłego już $\mathrm{w}$ dokumentach synodalnych z IV w. n.e. „inquietandi enim sanctorum spiritus non sunt"30 (BlChr, s. 737, pkt 7), utarło się też określenie sanctae memoriae - 'świętej pamięci', które było szeroko reprezentowane w tekstach średniowiecznych (por. np. BlChr, s. 524, pkt 1; DMLB, s. 2926, pkt 3b).

\footnotetext{
28 „Mnisi prawdziwie świeci”.

„Mój Paulinie, święty boży człowieku”.

„Nie należy zatem niepokoić dusz zmarłych”.
} 
Na miano osobnej kategorii znaczeń w obrębie opisu osób zasługuje zaadaptowanie przymiotnika sanctus do funkcji tytułu honorowego. Jak wspomniano wyżej, zaczątki takiego użycia odnaleźć można w późniejszej starożytności w odniesieniu do cesarzy rzymskich, jednak nie było to powszechne. Inaczej miała się sprawa z innymi przymiotnikami desygnującymi m.in. 'świętość, 'szczęście', 'boskość, a więc augustus, divus, felix. Wyrazy te stanowiły element oficjalnej tytulatury cesarzy (por. OLD, s. 214 pkt 1a; s. 566 pkt c), w późniejszych zaś epokach stały się titula honorifica papieży, biskupów i innych dostojników kościelnych (np. LIML s. 191). Sanctus w stopniu równym i najwyższym zaczęło funkcjonować w podobnej funkcji w oficjalnych dokumentach kościelnych oraz epistolografii chrześcijańskiej już u zarania średniowiecza, zwłaszcza w bezpośrednich zwrotach do adresata (BlChr, s. 737, pkt 8; LLNM, s. S82, pkt II.2.b). Najciekawszym aspektem funkcjonowania omawianego słowa w tym zakresie jest utrwalenie znaczenia 'święty, czczony jako święty' jako swego rodzaju tytułu, jakkolwiek odsyłającego do przymiotów opisywanej osoby, to jednak mającego na celu przede wszystkim zaznaczenie w jakiś sposób jej wysokiej rangi w duchowej (nie organizacyjnej) strukturze wspólnoty chrześcijańskiej. Stwierdzenie, że określenie to odnosi się po prostu do osób kanonizowanych ociera się niestety o anachronizm, ponieważ procedura kanonizacyjna formowała się bardzo długo, właściwie dopiero od XII w. można mówić o kontroli papieży nad tym procesem (Zubka 1969; Misztal 2000, kol. 607-608), natomiast wspomniane zastosowanie sanctus można napotkać już u autorów żyjących na przełomie V i VI w. n.e., jak np. autor anonimowej Passio Rufinae et Secundae w VI w. (LIML, s. 701) czy Anonim z Piacenzy, autor itinerarium do Ziemi Świętej (VI w. n.e.), a także w mszałach kodyfikujących kształt liturgii gockiej czy mozarabskiej z wieku VII (BlChr, s. 737, pkt 9) i powszechnie w kolejnych wiekach. Sanctus w tym znaczeniu utrwaliło się w utartych określeniach, takich jak np. Sermones de tempore et de sanctis ${ }^{31}$ - bardzo często spotykanym tytule zbiorów kazań ${ }^{32}$, w wyrażeniu Omnes sancti na oznaczenie dnia 1 listopada obchodzonego jako dzień Wszystkich Świętych (DMLB, s. 2926, pkt 4 d; GMLS, s. 404, pkt II.1). Czasami można spotkać rozszerzenie lub wręcz przeniesienie drogą metonimii znaczenia 'osoba święta' na określenie grobowca lub relikwii osoby świętej (DMLB, s. 2927, pkt. 5b).

Sanctus w literaturze kościelnej i średniowiecznej odnosi się oczywiście również do wszelkich rzeczy poświęconych Bogu w sensie dosłownym i metaforycznym. Wśród wielu rozmaitych kolokacji i leksykalizacji form zsubstantywizowanych kilka zasługuje na szczególną uwagę. W Księdze Wyjścia przy opisie sposobów namaszczania i okadzania Arki Przymierza oraz namiotu spotkania

\footnotetext{
31 Kazania na różne części roku i dni poświęcone świętym.

32 Por. Peregryn z Opola 1997.
} 
napotykamy superlativus hebraicus o brzmieniu sanctum sanctorum ${ }^{33}$, który w późniejszym czasie dał początek określeniu części kościoła znajdującej się najbliżej ołtarza, czyli prezbiterium (MLM, s. 937, pkt 2; DMLB, s. 2927, pkt 5d; GMLS, s. 404, pkt. II.3). Z kolei rzeczownik sanctum w rodzaju nijakim urobiony od omawianego przymiotnika oznaczał wówczas 'sanktuarium, klasztor' (MLM, s. 937, pkt 2; LIML, s. 702). Zsubstantywizowane zaś neutrum plurale - sancta (MLM, s. 937, pkt 2; LLNM, S 83, pkt B.1.c), podobnie jak junktury sanctus cibus (LIML, s. 702), sanctum Domini (DC, s. 737, pkt 10.c) opisywały konsekrowaną hostię. Ważne połączenie, które ma swe korzenie w starożytności, tworzy sancta dies - 'dzień święty, święto', a także pokrewne mu eliptyczne sformułowania używane dla oznaczenia daty, jak in sancta Epiphania, sancta quadragesima (BlChr, s. 736, pkt 3), lub inne zawierające imię świętego i odnoszące się do dnia w kalendarzu, gdy przypadało jego święto, a pojawiające się w rozmaitych rachunkach i dokumentach (DMLB, s. 2926, pkt 2.c) ${ }^{34}$. Na koniec warto jeszcze wyszczególnić odnotowane w słowniku łaciny ze źródeł brytyjskich pospolite użycie przymiotnika w nazwach roślin, takich jak: sanctae spinae - jakiś ciernisty krzew, sigillum sanctae Mariae - być może Tamus communis, czyli 'przestęp czarny'35 (DMLB, s. 2926, pkt 2d) oraz odnotowane tylko w słowniku łaciny jugosłowiańskiej zastosowanie w nazwie tkaniny sanctus Ilaresus (GMLI, s. 1034).

Hasło sanctus w Słowniku łaciny średniowiecznej w Polsce powstało na podstawie 130 wypisów źródłowych ${ }^{36}$. Jego zawartość nie różni się znacząco od leksykograficznego opisu tego przymiotnika w innych, przywoływanych wyżej publikacjach. Pierwszy punkt główny odnosi się do przymiotnika w funkcji przydawki i obejmuje znaczenia 1. 'święty, cieszący się chwałą świętych, czczony jako święty', 2. 'noszący znamię świętości, czysty, nieskazitelny, doskonały', 3. 'poświęcony Bogu, święty, sakralny, uroczysty' Tutaj również opisano pod podpunktem 4. funkcję sanctus jako tytułu honorowego w odniesieniu do władców świeckich oraz osób duchownych. Drugi punkt główny obejmuje urzeczownikowione postaci omawianego wyrazu, a więc sanctus, -i na określenie osoby świętej; sanctum, -i na określenie świętego przedmiotu, a także święta, świętego dnia; sancta, -orum oddano z kolei jako 'to, co święte, świętość', w lokucji zaś sancta sanctorum 'największe świętości' lub 'ołtarz', co stanowi interesujące zwężenie znaczenia w stosunku do łaciny opisanej w pozostałych słownikach narodowych (SŁŚ

33 „Sanctum sanctorum erit uobis thymiama” (Vlg. Ex 30, 36), „Kadzidło będzie dla was rzeczą najświętszą".

34 Por. np. Wierzchowski 1926, s. 1-49. Znajduje się tam repertorium dat związanych z obchodami świąt poszczególnych ich patronów z uwzględnieniem obyczajów panujących w średniowieczu w poszczególnych diecezjach Kościoła katolickiego w Polsce.

35 Identyfikacja podana przy haśle sigillum w DMLB, s. 3076, pkt 11a.

36 Por. wyżej, przyp. 2. 
kol. 675). Autorzy SŁŚ, zgodnie z przyjętymi zasadami redakcyjnymi (Plezia 1988), wyszczególniają zwłaszcza te osobliwości znaczeniowe i cechy składni wyrazów, które charakterystyczne są dla epoki poklasycznej, a występują w badanych tekstach. Za takie uznano nietypowe połączenie gramatyczne $\mathrm{z}$ ablatiwem wyrażającym przyczynę - „sancta erat [uxor Zlaunici] moribus, sancta sermonibus"37 (SŁŚ kol. 675, pkt I.2) ${ }^{38}$, a także appellationem honorificam ludzi Kościoła i wszystkie przypadki substantywizacji prócz pierwszego (sanctus, $-i$ ).

Należy zdać sobie sprawę, iż mimo naukowego charakteru przywoływanych tutaj słowników łaciny średniowiecznej, w tym polskiej, i ogromu zgromadzonych tam informacji nie dają one pełnej odpowiedzi na wiele pytań odnośnie do semantyki i gramatycznego funkcjonowania badanych wyrazów (a także grafii i wielu innych aspektów języka historycznego w jego kilkusetletnim rozwoju) $)^{39}$. Dzieje się tak dlatego, że leksykografowie muszą postępować zgodnie z obranymi zasadami redakcyjnymi (Stotz 2002, s. 193-235), które zawsze pozostają kwestią arbitralnych wyborów ${ }^{40}$. I tak komitet redakcyjny Słownika łaciny średniowiecz$n e j w$ Polsce pod kierunkiem prof. Mariana Plezi podjął u zarania tego przedsięwzięcia decyzję, by kładąc nacisk na uwypuklenie tego, co w polskiej łacinie średniowieczne, świadomie pominąć uszczegółowienie i ilustrację źródłową znaczeń wywodzących się ze starożytności (Plezia 1948 [2001], s. 32-34; Rzepiela 2010b, s. 14-17). Efektem tych wyborów, w kontekście prezentowanych tu badań nad semantyką historyczną polskiej łaciny średniowiecznej, jest niemożność określenia na podstawie danych zaczerpniętych wyłącznie ze Słownika faktycznej frekwencji danych sensów i łączliwości (tak starożytnych, jak i średniowiecznych) i płynąca stąd obawa o wytworzenie fałszywego obrazu. Dodatkowo liczba cytatów przytoczonych w słowniku tradycyjnym z konieczności musi być ograniczona i nie jest możliwe automatyczne uporządkowanie ich wedle pożądanych kryteriów, takich jak czas i miejsce powstania, gatunek literacki itp.

Te i inne postulaty badawcze mogą jednak zostać zrealizowane za pomocą innego narzędzia pracy poręcznego dla historyka języka, a mianowicie korpusu. W latach 2012-2016 w Pracowni Łaciny Średniowiecznej IJP PAN realizowany był projekt „Fontes Mediae et Infimae Latinitatis Polonorum. Korpus łaciny

37 „[Żona Sławnika] święta była pod względem obyczajów, święta w swej mowie”.

38 SŁŚ w pkt I.1 cytuje również połączenie z post, jednak w mniemaniu autorki artykułu nie jest to połączenie charakterystyczne dla tego akurat przymiotnika, lecz powszechne użycie czasowe przyimka niezależne od otoczenia leksykalnego.

39 Jakkolwiek również materiał słownikowy dostarcza danych do prowadzenia interesujących badań, na przykład nad zagadnieniem zmiany językowej w polskiej łacinie średniowiecznej, por. Nowak 2015.

40 Dodatkowa trudność wynika $\mathrm{z}$ wątpliwości samych leksykografów co do poprawnego oddania znaczeń, a także, jak pisze Rzepiela: „szukania właściwej proporcji w opisie słownikowym dla zjawisk w języku jednostkowych i regularnych” (Rzepiela 2010a, s. 142). 
średniowiecznej na ziemiach polskich 1000-1550" finansowany przez NPRH. W jego ramach powstał wewnętrznie ustrukturyzowany zbiór tekstów wzbogaconych o metadane zawierające informacje o czasie i miejscu pochodzenia, autorze, rejestrze, gatunku literackim i wiele innych. Korpus opracowano w XML $\mathrm{z}$ tagowaniem zgodnym $\mathrm{z}$ wytycznymi konsorcjum TEI dla tekstów historycznych, starając się przy tym o zachowanie jego reprezentatywności i zrównoważenia (Nowak 2014a).

Doświadczenia związane $\mathrm{z}$ budową e-Fontes stały się inspiracją do wyodrębnienia zeń niewielkiego subkorpusu polskiej hagiografii średniowiecznej, w którego skład wchodzą Vitae et Miracula. Pod uwagę wzięte zostały zapisy o świętych i błogosławionych związanych z szeroko pojętym terytorium Polski, o których pamięć funkcjonowała na naszych ziemiach i znajdowało to odzwierciedlenie w piśmiennictwie (Schenk 1966; Starnawski 1993). Tak więc badaniu poddano utwory dotyczące świętego Wojciecha ${ }^{41}$, Ottona ${ }^{42}$, Stanisława ${ }^{43}$, Jacka ${ }^{44}$, Floriana ${ }^{45}$, bł. Wernera ${ }^{46}$, a także świętej Jadwigi Śląskiej ${ }^{47}$, Jadwigi Andegawenki ${ }^{48}$ i Kingi ${ }^{49}$ oraz błogosławionych Anny ${ }^{50}$ i Salomei ${ }^{51}$. Ograniczenie gatunkowe miało na celu wydzielenie w miarę jednorodnej stylistycznie i spójnej językowo części ze spuścizny hagiograficznej wieków średnich, nie bez znaczenia była również kwestia słabej dostępności wydań krytycznych tekstów liturgicznych, legend brewiarzowych i kazań, która wpłynęła na ich reprezentację w korpusie głównym. Mimo tego zawężenia specjalny subkorpus hagiograficzny liczy 234455 wyrazów, w tym 73645 dotyczy świętych kobiet, a 160810 mężczyzn. Wyżej wymienione teksty procesowano za pomocą wielonarzędziowej platformy TXM (Heiden et al. 2010a; Heiden 2010b). Lemmatyzacja i anotacja części mowy (POS) są dostępne dzięki zintegrowanemu z platformą TXM programowi TreeTagger (Schmid 1994; Schmid 1995) przy zastosowaniu zestawu parametrów dla języka łacińskiego autorstwa Gabriele Brandoliniego, po przetestowaniu dwóch innych zestawów ${ }^{52}$.

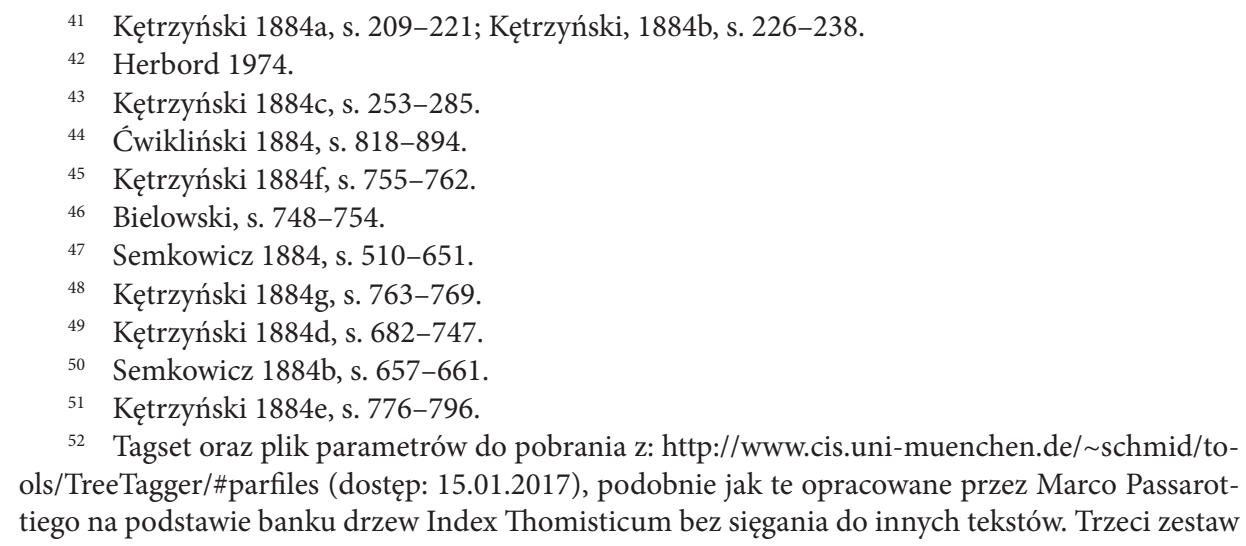

52 Tagset oraz plik parametrów do pobrania z: http://www.cis.uni-muenchen.de/ schmid/tools/TreeTagger/\#parfiles (dostęp: 15.01.2017), podobnie jak te opracowane przez Marco Passarottiego na podstawie banku drzew Index Thomisticum bez sięgania do innych tekstów. Trzeci zestaw 
Trzeba tu przy tym poczynić zastrzeżenie, że tagowanie części mowy na materiale łaciny ziem polskich nie daje, jak dotąd, zadowalających rezultatów przy zastosowaniu istniejących setów parametrów ze względu na typowe dla tych terenów zróżnicowane również chronologicznie warianty grafii, które nie występują w Corpus Thomisticum stanowiącym jedną z podstaw (jako exemplum literatury średniowiecznej) do treningu Treetaggera dla łaciny. $Z$ tego rodzaju problemami mierzyć się muszą wszyscy językoznawcy opierający swe badania na korpusach tekstów historycznych (Piotrowski 2012, s. 11-23). Jednak ze względu na niewielką ilość tekstu poddaną obserwacji nie okazało się to przeszkodą. Prezentowane tu badania korpusowe opierają się głównie na obliczeniach frekwencji, analizie konkordancji i próbie zaobserwowania z jednej strony powtarzalnych wzorów, w tym wypadku wzorów współwystępowania określonych leksemów (Sinclair 2001; McEnery 2012), a z drugiej wszelkich ciekawych zjawisk, nawet efemerycznych, ponieważ korpus tego rozmiaru nie stanowi wystarczającej bazy dla ściśle kwantytatywnych wniosków, zaś semantyka historyczna zawsze wymaga wracania z poziomu słownika czy konkordancji do szerszych kontekstów dostępnych jedynie poprzez „czytanie z bliska”.

Podstawowe obserwacje dotyczą frekwencji. Elektroniczny Korpus Łaciny Średniowiecznej e-Fontes, w zamyśle reprezentujący w sposób zrównoważony tytułowy zasób językowy, zawiera 11950 wystąpień omawianej lemmy (co daje 2394 wystąpień na milion ${ }^{53}$ ). Natomiast w Korpusie Polskiej Hagiografii Średniowiecznej bezwzględna liczba wystąpień lemmy sanctus wynosi 1497, zaś względna to 6385 na milion. Jak się wydaje, już ta prosta obserwacja wartości względnych wspiera zasadność prowadzenia badań na tekstach hagiograficznych, gdzie - jak się okazuje - koncentracja omawianego słowa jest dużo większa niż przeciętnie w łacinie polskiego średniowiecza.

Kolejny krok polegał na wydzieleniu dwóch subkorpusów zgodnie z podziałem na płci opisywanych w tekstach osób, a następnie sprawdzeniu frekwencji względnej i bezwzględnej przymiotnika sanctus w tych zbiorach. Wielkości te przedstawiają się następująco: w subkorpusie femininum frekwencja bezwzględna sięga 560 wystąpień, względna zaś 7604 na milion; 937 wystąpień odnotowano natomiast w subkorpusie męskim, co daje frekwencję względną na poziomie 5827 na milion. Zwraca uwagę wyraźnie częstsze użycie lemmy sanctus w tekstach poświęconych świętym kobietom.

Wobec tego przeprowadzono następny eksperyment polegający na sprawdzeniu, w jaki sposób przymiotnik sanctus łączy się z rzeczownikami i nazwami własnymi wskazującymi na osobę, by sprawdzić, czy uzyskany wcześniej wynik

parametrów został opracowany w ramach projektu OMNIA prowadzonego w IRHT CNRS i jest dostępny pod adresem: http://www.glossaria.eu/treetagger/ (dostęp: 15.01.2017).

53 Wartości frekwencji uśrednionej do miliona podaję w zaokrągleniu do jednego. 
wiąże się z częstszym określaniem świętych kobiet tym mianem. Rzeczowniki wyodrębniono poprzez ocenę listy lemmatów najczęściej współwystępujących w najbliższym otoczeniu przymiotnika sanctus ${ }^{54}$ (konteksty prawy i lewy pięciowyrazowe $^{55}$, przy czym liczba współwystąpień nie mogła być mniejsza niż 5). W kolejności frekwencji są to: dominus (93 współwystąpienia w opisywanym kontekście, w większości jednak bez ścisłego związku składniowego z sanctus), vir (73), domina (20), martyr (18 w stosunku do mężczyzn, 2 do kobiet). Ponadto oceniono, ile razy męskie i żeńskie imiona świętych występowały na wyżej wspomnianej liście współwystąpień: sanctus $N .=447$, sancta $N .=242$.

Uzyskane wyniki mogą skłaniać do podziału opisywanych osób zgodnie z płcią. Jak widać, określenie sanctus aplikowane jest w danym zborze tekstów częściej do rzeczowników oznaczających mężczyzn, z zastrzeżeniem, że słowo dominus odnosi się w większości wystąpień do Boga. Zbitka domina sancta występuje dużo rzadziej. Połączenie sanctus(a) N., gdzie przymiotnik funkcjonuje jako rodzaj tytułu honorowego, jak to już wcześniej wspomniano, podąża za zarysowanym powyżej trendem. Niejednokrotnie można spotkać w tekstach z tego okresu podobne zjawiska. Za przerysowany przykład niech posłuży kazanie XV-wiecznego dominikanina Jana z Ząbkowic, w którym słowo mulier nie występuje inaczej aniżeli w zbitce mulier nequam - niegodziwa kobieta ${ }^{56}$. Oczywiście tego rodzaju obserwacja poczyniona na niewielkim wycinku spuścizny polskiego średniowiecza nie może służyć do wysnuwania żadnych wniosków natury ogólnej, tym bardziej że należałoby ocenić uprzednio rolę konwencji literackiej w tego typu tekstach, a także ogólnie postrzeganie miejsca kobiet w społeczeństwie $\mathrm{w}$ badanym okresie $\mathrm{e}^{57}$, które to zagadnienia wykraczają dalece poza zakres i metody prezentowanych tu badań. Niemniej można mieć nadzieję, że obserwacje prowadzone w przyszłości na szerszym materiale mogą przynieść dalsze interesujące wyniki odnośnie do choćby leksykalnego konstruowania wzorca świętości dla kobiet i mężczyzn na przestrzeni pięciuset lat polskiego średniowiecza, być może - w miarę zwiększania się dostępności tekstów publikowanych w formie elektronicznej - również w kontekście średniowiecza europejskiego.

Szerszych informacji dostarcza narzędzie TXM do ekstrahowania kolokacji. Wyniki podzielone są tam na cztery kategorie: liczba wystąpień słowa

54 Wykorzystano wbudowane w platformę TXM narzędzie służące do ekstrahowania kookurencji. Wyniki dodatkowo oceniono pod kątem istnienia związku zgody pomiędzy rzeczownikiem a przymiotnikiem sanctus lub innego związku składniowego typowego dla opisu osób i rzeczy (por. niżej) i tylko te przykłady uwzględniono.

55 Lingwiści zajmujący się przetwarzaniem języka naturalnego zwyczajowo przyjmują taką rozpiętość kontekstu słowa badanego pod kątem kolokacji. Por. np. Seretan, Wehrli 2007, s. 75.

56 Por. Ledzińska, Zajchowska 2011.

57 Michalski 2004, s. 10-12. 
współwystępującego ogółem w tekście, liczba współwystąpień, średni dystans, który dzieli je od słowa badanego oraz wynik obliczeń statystycznych szacujących siłę kolokacji danego połączenia ${ }^{58}$. Na potrzeby niniejszych obserwacji nie korzystano z wyżej wspomnianych miar statystycznych, ponieważ liczba współwystąpień umożliwia ich lekturę i ocenę przez badacza ${ }^{59}$, chroniąc rzadsze, a niejednokrotnie ciekawe połączenia przed pominięciem ${ }^{60}$. Przyjęto szerokie rozumienie terminu kolokacja jako częstego i bliskiego współwystępowania dwóch leksemów, niekoniecznie następujących bezpośrednio po sobie ${ }^{61}$.

Pewnym zaskoczeniem może być fakt, że nawet przy ustawieniu dość szerokich kontekstów (10 wyrazów z prawej i 10 z lewej strony) w zestawieniu współwystąpień lemmy sanctus (zweryfikowanym poprzez lekturę pojawiających się słów z badanego zakresu w kontekście) praktycznie nie pojawiają się określenia rzeczownikowe w składni charakterystycznej dla łacińskiego sposobu deskrypcji (Stotz 1998, s. 235-286), wyrażenia przyimkowe ani przymiotnikowe przydawki opisujące cechy świętych osób (Wolanin 2012, s. 572-578). Znaczyłoby to, że zestaw cech wiązanych ze świętością w literaturze hagiograficznej będzie dość szeroki i rozproszony i nie stanowi pewnego stałego zasobu.

Lista kolokacji (z wyłączeniem wyrazów funkcyjnych) występujących częściej niż 20 razy w badanym zasobie, w kolejności frekwencji, przedstawia się następująco: Deus (168), sepulcrum (114), dico (87), meritum (81), ecclesia (68), dies (61), invoco (48), spiritus (47), vita (42), ordo (38), venio (36), devoveo (35), limen (31), voveo (30), visito (30), votum (30), capio (28), duco (27), auxilium (26), honor (25), oro (20), tumulus (20).

W świetle wcześniejszych obliczeń warto podkreślić, że pośród dominujących kolokacji na plan pierwszy wysuwa się połączenie sanctus/sancta N. (689), choć niewiele im ustępują sanctus Dei oraz sanctus Spiritus czy ecclesia, dies (w znaczeniu 'dnia świętego, święta'). Mniej ścisły (czasami składniowy, przeważnie kontekstowy) związek można zaobserwować pomiędzy sanctus a sepulchrum oraz tumulus w znaczeniu 'grobowiec osoby świętej', zwłaszcza taki, do którego się pielgrzymuje, by uzyskać potrzebne łaski (w tym kontekście częsty czasownik visito). Podobne znaczenie daje dość częsty w zestawieniach współwystępowania rzeczownik limen, dosł. 'próg', a metonimicznie - 'dom, grobowiec, przybytek, miejsce poświęcone danemu świętemu’, a także mniej częsty (10) tumba.

58 Obliczenie siły współwystąpień w TXM opiera się na rachunku tzw. specyficzności (spécificités). Por. Lafon 1980, a także: podręcznik platformy TXM online: http://txm.sourceforge.net/doc/ manual/manual34.xhtml\#toc132 (dostęp: 15.01.2017) oraz http://txm.sourceforge.net/doc/manual/manual36.xhtml\#toc141 (dostęp j.w.).

59 Sinclair 1991, s. 115-21.

60 Stubbs 2001, s. 71.

61 Za: Sinclair, Jones, Daley, Krishnamurthy 2004, s. 10. 
Dużą frekwencją cieszy się połączenie lemm sanctus oraz meritum, które występują przeważnie w tych kontekstach, gdy mówi się o pozyskiwaniu łask za wstawiennictwem świętych, dzięki ich zasługom. Tu pojawia się kolokacja z czasownikiem invoco, gdzie z reguły chodzi o przyzywanie pomocy (auxilium) świętych, a także devoveo i voveo - składanie uroczystych przysiąg, ślubowanie czegoś przy grobie świętego w zamian za potrzebne łaski. Te wzory współwystępowania wyrazów związanych z wyrazem sanctus pozwalają się zorientować, jakie są najważniejsze tematy pojawiające się w dziełach hagiograficznych tego okresu i dotyczące świętych osób. Jest to tylko skromna próbka możliwych kwerend. Wobec szybkiego przybywania dostępnych publicznie tekstów w wersji cyfrowej, a także rozwoju narzędzi korpusowych dla języków historycznych ten kierunek badań wydaje się obiecujący. Prowadzone są tego typu projekty dla łaciny, tak klasycznej, jak i późniejszej (np. McGillivray 2014; Geelhaar 201562), jednak łacina ziem polskich nie doczekała się jeszcze tego typu kompleksowych badań.

Warto podkreślić, że wykorzystanie specjalistycznych subkorpusów, jak również reprezentatywnego Elektronicznego Korpusu Łaciny Średniowiecznej może stanowić wsparcie dla leksykografów redagujących Słownik łaciny średniowiecznej w Polsce. Kwerendy takie, jak zaprezentowane powyżej, umożliwiają nieintuicyjne wyróżnianie charakterystycznych kolokacji i związków syntagmatycznych gromadzonych w SŁŚ pod etykietami locutiones, iuxta posita, iuncturae oraz constructiones. Możliwa staje się obiektywizacja w ocenie frekwencji opisywanych zjawisk, a także ogląd pełnego obrazu języka niepomijający użyć słowa w znaczeniu klasycznym, a co za tym idzie, lepszy wgląd w rozwój znaczeń i inne zmiany językowe. Ponieważ SŁŚ posiada już swoją wersję elektroniczną ${ }^{63}$, istnieje możliwość modyfikowania haseł już istniejących $\mathrm{z}$ wykorzystaniem danych korpusowych.

Reasumując, można stwierdzić, że w trakcie wielowiekowego rozwoju przymiotnika sanctus jego znaczenia uległy rozwojowi głównie pod wpływem doktryny chrześcijańskiej. Wszystkie znaczenia klasyczne pozostały obecne w języku w późniejszych epokach, jednak w nowym kontekście kulturowym zyskały dodatkowe komponenty semantyczne i zaczęły tworzyć innego rodzaju związki międzywyrazowe. Odnosi się to przede wszystkim do przydawkowych opisów osób Trójcy Świętej pojawiających się w miarę kształtowania się dogmatów, gdzie pobrzmiewają często wzorce zaczerpnięte $\mathrm{z}$ hebrajskiej Biblii - tersanctus, sanctus sanctorum. W formie urzeczownikowionej sanctus staje się wręcz synonimem Deus. Podobnie w funkcji deskryptywnej przymiotnik odnoszony był do ludzi wiodących życie

${ }^{62}$ Autor prezentuje badania $\mathrm{z}$ zakresu semantyki historycznej wsparte metodami cyfrowymi. Jest współtwórcą narzędzia CompHistSem: http://www.comphistsem.org/home.html (dostęp: 15.01.2017).

63 Dostępną pod adresem www.scriptores.pl/elexicon. Por. Nowak 2014b. 
dobre, moralnie nieposzlakowane, godne świętego, a w formie zsubstantywizowanej stanowił synonim takich osób, np. patriarchów, męczenników, apostołów, a także szerzej ludzi wiernych Bogu, członków Kościoła, chrześcijan. Już w starożytności opisywana jednostka leksykalna stała się elementem oficjalnej tytulatury najważniejszych dla społeczności osób, a w średniowieczu ta funkcja appellatio honorifica w pewien sposób została rozszerzona na osoby uznawane za święte (nawet jeśli ich kult nie był usankcjonowany przez Kościół), do których modlono się o wstawiennictwo i które stanowiły wzór osobowy w zbiorowej wyobraźni. Opis przedmiotów również podporządkowany był naczelnej zasadzie ich przynależności do Boga w sensie dosłownym i metaforycznym, a także - podobnie jak miało to miejsce w przypadku osób i bóstwa - mógł się wyrażać poprzez określającą je przymiotnikową przydawkę lub substantivum stanowiące synonim jakiegoś obiektu. Tak więc sanctum sanctorum określenie miejsca najświętszego zaczerpnięte z Pisma Świętego Starego Testamentu przeniesione zostało na prezbiterium, a w łacinie polskiej na sam ołtarz. Sanctus cibus i podobne złożenia desygnowały hostię. Przymiotnik sanctus w odniesieniu do dies lub festum, a także w odniesieniu do świętych katolickich w kontekście dni im dedykowanych stał się częścią systemu określania dat w średniowieczu. Jak widać, wyraz ten odgrywał w języku dawnych wieków ważną rolę konceptualną i praktyczną, a niewielka próba badań łaciny ziem polskich oparta na metodach korpusowych pokazuje, że szersze badania kwantytatywne tak łaciny polskiej, jak i europejskiej wieków średnich mogą przynieść jeszcze wiele ciekawych wniosków odnośnie wzorów współwystępowania przymiotnika sanctus, jego frekwencji w różnych znaczeniach na przestrzeni czasu, a nawet społecznych uwarunkowań jego aplikacji do różnych osób i grup ludzkich.

\section{Słowniki - skróty}

BlChr - A. Blaise, Dictionnaire latin-francaise des auteurs chrétiens, Strasbourg 1954;

BIM - A. Blaise, Lexicon latinitatis medii aevi praesertim ad res ecclesiasticas investigandas pertinens, Brepols 1975;

DMLB - The Dictionary of Medieval Latin from British Sources, ed. R.E. Latham et al., London-Oxford 1975-2013;

GMIL - Glossarium mediae et infimae Latinitatis, wyd. Ch.F. Du Cange, Parisiis 1937;

GMLC - Glossarium Mediae Latinitatis Cataloniae ab anno DCCC usque ad annum MC, ed. M. Bassols de Climent Iohannes Bastardas Parera et al., Barcelona 1960;

GMLF - Glossarium Latinitatis Medii Aevi Finlandicae, ed. R. Hakamies, Helsinki 1958;

GMLF - M. Hammarström, Glossarium till Finlands och Svergies Latinska Medeltidsurkunder jämte spraklig inlending, Helsingfors 1925; 
GMLH - Glossarium mediae et infimae Latinitatis regni Hungariae, ed. A. Bartal, Leipzig-Budapest 1901;

GMLI - Glossarium Mediae Latinitatis Iugoslaviae, ed. M. Kostrenčić, Zagreb 1973-1978;

GMLS - Glossarium Mediae Latinitatis Sueciae / Glossarium till medeltidslatinet i Sverige, ed. U. Westerbergh / E. Odelman, t. I-II, Stockholm 1968-2002;

LD - A new Latin Dictionary founded on latin translation of Freund' Latin-German Lexicon ed. by E.A. Andrews, ed. ChT. Lewis, Ch. Short, New York 1891;

LIML - Latinitatis Italicae medii aevi lexicon (saec. V ex.-saec. XI in.), ed. F. Arnaldi, P. Smiraglia, 2 ed., Tavarnuzze-Impruneta-Firenze 2001;

LLNM - Lexicon Latinitatis Nederlandicae Medii aevi / Woordenboek van het middeleeuws Latijn van de noordelijke Nederlanden. Conditum a Johanne W. Fuchs, ed. O. Weijers / M. Gumbert-Hepp, Leiden-Amsterdolami 1977-2005;

MLM - J. F. Niermayer, Mediae Latinitatis Lexicon Minus, Leiden 1976;

MLW - Mittellateinisches Wörterbuch bis zum augestehenden 13. Jahrhundert, Münich 1959.

LMB - Latinitatis Medii Aevi Lexicon Bohemorum, Pragae 1977;

LMH - Lexicon latinitatis mediiaevi Hungariae, ed. J. Harmatta, I. Bronkoi, Budapest 1987;

OLD - Oxford Latin Dictionary, ed. P.G.W. Glare et. al., Oxford 1968;

SŁK - A. Jougan, Słownik kościelny łacińsko-polski, wyd. 3, Poznań 1958;

SŁP - Słownik łacińsko-polski, red. J. Korpanty, t. 2, Warszawa 2003;

SŁŚ - Słownik łaciny średniowiecznej w Polscel Lexicon mediae et infimae latinitatis Polonorum, red. M. Plezia et al., Wrocław-Warszawa-Kraków-Gdańsk-Łódź 1953-;

ThLL - Thesaurus Linguae Latinae editus auctoritate et consilio academiarum quinque Germanicarum: Berolinensis, Gottigensis, Lipsiensis, Monacensis, Vindobonensis; bzw. ab 1949 Thesaurus Linguae Latinae editus iussu et auctoritate consilii ab academiis societatibusque diversarum nationum electi, Leipzig 1900 ad 1990, Stuttgart ab 1991;

TLForc - Totius Latinitatis Lexicon, ed. E. Forcellini et al., Prati 1858-60.

\section{Bibliografia}

Bielowski, A. (wyd.) (1884). Mors et miracula beati Verneri, episcopi Plocensis, auctore Ioanne, decane Plocensi. W: Pomniki dziejowe Polski. T. 4 (748-754). Lwów: nakładem Akademii Umiejętności.

Blaise, A. (1966). Le vocabulaire latin des principaux thèmes liturgiques. Turnhout: Brepols. Bourgain, P. (2005). Le latin médiéval. Turnhout: Brepols.

Brown, S.F. (1996). Theology and philosophy. W: F.A.C. Mantello, A.G. Rigg (ed.), Medieval Latin. An introduction and Bibliographical guide (93-105). Washington: The Catholic University of America Press. 
Ćwikliński, L. (wyd.) (1884). De vita et miraculis sancti Iacchonis (Hyacynthi) ordinis fratrum praedicatorum auctore Stanislao lectore Cracoviensi eiusdem ordinis. W: Pomniki dziejowe Polski. T. 4 (818-894). Lwów: nakładem Akademii Umiejętności.

Fugier, H. (1963). Recherches sur l'expression du sacré dans la langue latine, Paris: Société d'Édition, Les Belles Lettres.

Geelhaar, T. (2015). Christianitas. Eine Wortgeschichte von der Spätantike bis zum Mittelalter. Götingen: Vanderhoek\&Ruprecht.

Guerreau-Jalabert, A. et al. (wyd.) (2015). Novum glossarium mediae latinitatis ab anno DCCC usque ad annum MCC. Pleguina-polutus. Bruxelles: U.A.I.

Hays, G. (2007). Latin from A to P: The TLL in the 20th Century, Transactions of the American Philological Association, 137(2), 483-90.

Heiden, S., Magué, J-P., Pincemin, B. (2010a). TXM : Une plateforme logicielle opensource pour la textométrie - conception et développement. W: I.C. Sergio Bolasco (red.), Proceedings of 10th International Conference on the Statistical Analysis of Textual Data - JADT 2010. Vol. 2 (1021-1032). Roma: Edizioni Universitarie di Lettere Economia Diritto.

Heiden, S. (2010b). The TXM Platform: Building Open-Source Textual Analysis Software Compatible with the TEI Encoding Scheme. W: K.I. Ryo Otoguro (red.), 24th Pacific Asia Conference on Language, Information and Computation-PACLIC24 (389-398). Sendai: Institute for Digital Enhancement of Cognitive Development.

Henderson, J. (2010). A1-ZYTHUM: DOMIMINA NUSTIO ILLUMEA, or Out with the OLD (1931-1982). W: Ch. Stray (red.), Classical dictionaries: past, present and future (139-76). London: Bristol Classical Press.

Herbord (1974). Dialog o życiu św. Ottona Biskupa Bamberskiego. K. Liman, J. Wikarjak (wyd.). Warszawa: Państwowe Wydawnictwo Naukowe.

Kętrzyński, W. (wyd.) (1884a). De sancto Adalberto episcopo. W: Pomniki dziejowe Polski. T. 4. (209-221). Lwów: nakładem Akademii Umiejętności.

Kętrzyński, W. (wyd.) (1884b). Miracula sancti Adalberti. W: Pomniki dziejowe Polski. T. 4. (226-238). Lwów: nakładem Akademii Umiejętności.

Kętrzyński, W. (wyd.) (1884c). Vita s. Stanislai episcopi Cracoviensis (vita minor). W: Pomniki dziejowe Polski. T. 4. (253-285). Lwów: nakładem Akademii Umiejętności.

Kętrzyński, W. (wyd.) (1884d). Vita et miracula sanctae Kyngae ducissae Cracoviensis. W: Pomniki dziejowe Polski. T. 4. (682-747). Lwów: nakładem Akademii Umiejętności.

Kętrzyński, W. (wyd.) (1884e). Vita sanctae Salomeae reginae Haliciensis auctore Stanislao Franciscano. W: Pomniki dziejowe Polski. T. 4. (776-796). Lwów: nakładem Akademii Umiejętności.

Kętrzyński, W. (wyd.) (1884f). Translatio sancti Floriani. W: Pomniki dziejowe Polski. T. 4. (755-762). Lwów: nakładem Akademii Umiejętności.

Kętrzyński, W. (wyd.) (1884g). Miracula beatae Hedwigis reginae Poloniae. W: Pomniki dziejowe Polski. T. 4. (763-769). Lwów: nakładem Akademii Umiejętności. 
Lafon, P. (1980). Sur la variabilité de la fréquence des formes dans un corpus, Mots/Ordinateurs/Textes/Sociétés, 1, 127-165.

Ledzińska, A. Zajchowska, A. (2011). „Mulier nequam” - kazania dominikanina Jana z Ząbkowic do kapituły wrocławskiej o celibacie i kapłańskiej czystości, Studia Źródłoznawcze, 48, 126-135.

Mazza, E. (1999). The Celebration of the Eucharist. The Origin of the Rite and the Development of Its Interpretation. Transl. M.J. O'Connell. Collegeville, Minnesota: Liturgical Press.

McEnery, T. Hardie, A. (2012). Corpus linguistics. Method, Theory and Practice. Cambridge: Cambridge University Press.

McGillivray, B. (2014). Methods in Latin computational linguistics. Leiden-Boston: Brill.

Michalski, M. (2004). Kobiety i świętość w Żywotach Trzynastowiecznych Księżnych Polskich. Poznań: Wydawnictwo Poznańskie.

Nowak, K. (2014a). Fontes Mediae et Infimae Latinitatis Polonorum. Z prac nad korpusem polskiej łaciny średniowiecznej, Polonica, 34, 105-114.

Nowak, K. (2014b). The eLexicon Mediae et Infimae Latinitatis Polonorum. The Electronic Dictionary of Polish Medieval Latin. W: A. Abel et al. (ed.), Proceedings of the XVI EURALEX International Congress: The User in Focus (15-19 July 2014, Bolzano/ Bozen) (793-806). Bolzano/Bozen: EURAC research.

Nowak, K. (2015). Language Change in the Dictionary of Polish Medieval Latin, Archivum Latinitatis Medii Aevi, 73, 309-319.

Peregryn z Opola. (1997). Sermones de tempore et de sanctis, red. R. Tatarzyński, A. Podsiad, Warszawa: Institutum Thomisticum PP. Dominicanorum Varsaviensium.

Piotrowski, M. (2012). Natural Language processing for Historical Texts. Toronto: Graeme Hirst, University of Toronto.

Plezia, M. (1948) [2001]. Projekt zasad redagowania słownika polskiej łaciny średniowiecznej. W: M. Plezia, Scripta minora. Łacina średniowieczna i Wincenty Kadłubek (23-46). Kraków: Wydawnictwo Naukowe PWN.

Plezia, M. (1988). Wstęp. W: Słownik łaciny średniowiecznej w Polsce. Zeszyt dodatkowy drugi. Wykaz dzieł cytowanych i skrótów (V-VIII). Wrocław-Warszawa-Kraków-Gdańsk-Łódź: Zakład Narodowy im. Ossolińskich.

Rzepiela, M. (2010a). Polska myśl językoznawcza a Słownik łaciny średniowiecznej w Polsce. W: B. Czopek-Kopciuch, P. Żmigrodzki (red.), Język polski-wczoraj, dziś, jutro (139-149). Kraków: Lexis.

Rzepiela, M. (2010b). Słownikłaciny średniowiecznej w Polsce - problemy metodologiczne w pracy nad słownikiem historycznym, Prace Filologiczne, 58, 369-378.

Schenk, W. (1966). Kult świętych w Polsce, zarys historyczny, Roczniki Teologiczno-Kanoniczne, 13 (4), 77-102.

Schilling, R. (1971). Sacrum et profanum, essai d'interprétation, Latomus, 30, 953-963. 
Schmid, H. (1994). Probabilistic Part-of-Speech Tagging Using Decision Trees. W: idem, Proceedings of International Conference on New Methods in Language Processing (4449). Manchester: UMIST.

Schmid, H. (1999). Improvements in Part-of-Speech Tagging with an Application to German. W: S. Armstrong et al. (red.), Natural language processing using very large corpora (13-25). Dordrecht: Springer Science+Business Media.

Schmitt, J.C. (1992). La notion de sacré et son application a l'histoire du christianisme medieval, Les Cahiers du Centre de Recherches Historiques, 9, 1-8. Pozyskano z http:// journals.openedition.org/ccrh/2798, (dostęp: 5.07.2018).

Semkowicz, A. (wyd.) (1884a). Vita sanctae Hedwigis. W: Pomniki dziejowe Polski. T. 4. (510-651). Lwów: nakładem Akademii Umiejętności.

Semkowicz, A. (wyd.) (1884b). Vita Annae ducissae silesiae. W: Pomniki dziejowe Polski. T. 4. (657-661). Lwów: nakładem Akademii Umiejętności.

Seretan, W., Wehrli, E. (2007). Multilingual collocation extraction with a Syntactic Parser, Language Resources and evaluation 43 (1), 71-85.

Sharpe, R. (1996). Vocabulary, word formation and lexicography. W: F.A.C. Mantello, A.G. Rigg (red.), Medieval Latin. An introduction and Bibliographical guide (93-105). Washington: The Catholic University of America Press.

Sinclair, J. (1991). Corpus, concordance, Collocation. Oxford: Oxford Univ. Press.

Sinclair, J. (2003). Reading concordances : an introduction. New York: Pearson/Longman.

Sinclair, J. Jones, S. Daley, R. Krishnamurthy, R. (2004). English Collocational Studies: The OSTI Report. London: Continuum.

Słomka, J. (2013). Trójca Święta. II. W Teologii. W: E. Gigilewicz (red.), Encyklopedia Katolicka. Szczepkowski-Użohorodzka unia (1049-1051). T. 19. Lublin: Towarzystwo Naukowe Katolickiego Uniwersytetu Lubelskiego Jana Pawła II.

Starnawski, J. (1993). Drogi rozwojowe hagiografii polskiej i łacińskiej w wiekach średnich, Kraków: Polskie Towarzystwo Teologiczne.

Stotz, P. (1998). Handbuch zur lateinischen Sprache des Mittelalters, Vierter Band. Formenlehre, Syntax un Stilistik. München: Verlag C.H. Beck.

Stotz, P. (2002). Handbuch zur lateinischen Sprache des Mittelalters, Erster Band. Einleitung, Lexikologische Praxis, Worter und Sachen Lehnwortgut. München: Verlag C.H. Beck.

Stubbs, M. (2001). Words and phrases: Corpus studies of Lexical Semantics. Oxford: Blackwell.

Wierzbowski, T. (1926). Vademecum. Podręcznik dla studiów archiwalnych. Lwów-Warszawa: Książnica-Atlas.

Wolanin, H. (2012). Gramatyka opisowa klasycznej łaciny w ujęciu strukturalnym. Kraków: Księgarnia Akademicka. 


\section{Streszczenie}

Artykuł omawia semantyczne funkcjonowanie przymiotnika sanctus na przestrzeni dziejów, poczynając od łaciny klasycznej poprzez kościelną aż do średniowiecznej, z uwzględnieniem regionalnego zróżnicowania języka. Przedmiotem szczególnego zainteresowania jest funkcjonowanie omawianego wyrazu w łacinie polskiego średniowiecza. Materiał porównawczy i egzemplifikacja zostały zaczerpnięte z rozmaitych słowników i leksykonów naukowych, zaś omówienia polskiej specyfiki znaczeń i łączliwości semantycznej dokonano na podstawie Słownika łaciny średniowiecznej w Polsce oraz Korpusu Polskiej Hagiografii Średniowiecznej, który powstał poprzez wydzielenie Żywotów i Cudów świętych polskich $\mathrm{z}$ większego korpusu łaciny średniowiecznej na ziemiach polskich. Materiał ten przeszukiwany był przy użyciu kwerend dostępnych na wielonarzędziowej platformie do procesowania danych korpusowych TXM. 